DOI: https://doi.org/10.32838/2523-4803/70-2-33

УДК 338.482

Кобченко А. $A$.

старший викладач кафедри маркетингу та міжнародного менеджменту,

Дніпровський національний університет імені Олеся Гончара

\title{
Kobchenko Andrii
}

Oles Honchar Dnipro National University

\section{ФОРМУВАННЯ МАРКЕТИНГОВИХ КОМУНІКАЦІЙ ТУРИСТИЧНОГО ПІДПРИЕМСТВА}

У статті досліджено та узагальнено теоретико-методичні підходи до формування маркетингових заходів на підприємстві туристичної галузі, а також представлено власне бачення та досліджено роль маркетингу в практичній діяльності туристичних підприємств у сучасних умовах господарювання. Розглянуто особливості функиіонування туристичного ринку. Запропоновано більш широке визначення маркетингових комунікацій з урахуванням уже наявних авторських підходів. Доведено, що розвиток інформачійних технологій та збільшення кількості засобів иифрової комунікації стали причинами переходу від постіндустріального суспільства до інформаційного, в якому основними факторами успіху стали знання, дані, телекомунікації як спосіб доставки та поширення иієї інформачії. Таким чином, для підприємств туристичної галузі виникає потреба диверсифікачії маркетингових комунікаиій для донесення інформації до споживачів за допомогою різних засобів комунікаиї, а також отримання зворотного зв 'язку, адже від ефективного використання маркетингового інструментарію залежить подальший розвиток туристичного підприємства в умовах ринку.

Ключові слова: маркетинг, туризм, маркетингові комунікації, інтегровані маркетингові комунікації, інструменти маркетингу.

Постановка проблеми. В останні десятиліття у світі відбулися зміни в розвитку інновацій, інформаційних технологій, отже, економіки, що приводить до зміни способу життя сучасної людини. Накопиченні матеріальні ресурси стали витрачатись не тільки на товари першої необхідності, але й на отримання нових вражень та задоволень, головною складовою частиною яких є туристичні подорожі.

Сьогодні сфера туризму розвивається дуже швидко та $є$ однією з провідних галузей економіки. Через актуальність теми планування відпочинку, екскурсійних турів тощо на ринку надання туристичних послуг перед підприємствами туристичної галузі постають завдання щодо ефективної реалізації товарів та послуг. До туристичних послуг включають весь спектр основних та додаткових послуг, що надаються різними організаціями туристичної галузі: від туристичних фірм до підприємств харчування.

Маркетингові заходи $€$ однією 3 найважливіших складових частин для просування товарів та послуг підприємства, стимулювання збуту, аналізування ринку та потенційних споживачів, що в подальшому приведе до отримання прибутку підприємством. Однак, на жаль, багато підприємств нехтують цим, не вважаючи за потрібне, або припускаються помилок у цій сфері.

Нестабільність зовнішнього середовища, високий рівень конкуренції серед підприємств туристичної сфери в умовах насиченого ринку змушують прово- дити переоцінку управління туристичними підприємствами та змінювати підходи до системи управління підприємством туристичної галузі.

Аналіз останніх досліджень і публікацій. Дослідженням та вивченням проблем та механізмів розвитку маркетингової діяльності підприємств туристичної галузі з урахуванням світового та вітчизняного досвіду займались такі науковці, як О.М. Азарян, Л.В. Балабанова, І.О. Башинська, В.В. Божкова, Т.В. Гринько, В.Г. Герасименко, І.З. Жук, Ю.Б. Забалдіна, А.С. Копанєва, О.О. Любіцева, М.П. Мальська, М.Г. Чумаченко, А.І. Хохотова, В.С. Янкевич.

Значний внесок у розроблення теоретичних засад формування маркетингового комплексу підприємств здійснили такі зарубіжні вчені, як Г. Ассель, Н. Борден, П. Дойль, М. Джефрі, Ф. Котлер, Ж.-Ж. Ламбен, С. Сеті, Х. Хершген, Р. Штойер.

Проте, незважаючи на велику кількість наукових та практичних здобутків, існує багато питань щодо ефективного використання маркетингу в діяльності підприємств туристичної галузі. Різноманіття наукових поглядів сучасних дослідників зумовлена безліччю наявних інструментів маркетингу та постійними інноваціями, зокрема інтернет-маркетингу, з чого випливає необхідність додаткового вивчення особливостей використання маркетингу на туристичному підприємстві.

Формулювання цілей статті. Метою статті $\epsilon$ дослідження та узагальнення теоретико-методичних 
підходів до формування маркетингових заходів на підприємстві туристичної галузі, а також розроблення рекомендацій щодо впровадження в практичну діяльність туристичних підприємств у сучасних умовах господарювання.

Виклад основного матеріалу. Протягом останніх десятиліть туризм економік різних країн перетворився на фундаментальну основу подальшого економічного розвитку. За оцінками Всесвітньої туристської організації (ВТО) кількість туристичних поїздок з 1950 р. зросла приблизно у 20-40 разів на всіх континентах світу, що підтверджує гіпотезу про значущість туристичної галузі у світовій економіці.

Популярність туризму можна обгрунтувати, наприклад, тим, що в піраміді Маслоу відпочинок виділяється як первинна фізіологічна потреба, задовольняти яку дають змогу товари та послуги підприємств туристичної галузі.

Великий вплив, зокрема, в соціальному аспекті туризм має не тільки на країну, але й на їі окремі регіони. Завдяки розвитку туризму більше грошових коштів проникає в регіони, що сприяє появі додаткових робочих місць, розвитку комунікаційних систем тощо. На одному рівні з перевагами розвитку туризму $\epsilon$ також деякі недоліки. Вони проявляються в тому, що туризм, наприклад, позитивно впливає на ціни на місцеві товари й послуги, нерухомість, що негативно позначається на достатку місцевих жителів, сприяє розвитку екологічних проблем, а також може заподіяти шкоди різним галузям економіки.

Функціонування туристичного ринку та пов'язаних будь-яким чином з ним підприємств туристичної галузі залежить від пори року. На сезонність в туризмі впливають різні фактори, зокрема кліматичні, психологічні (традиції, смаки й переваги), наявність вільного часу.

Щодо механізму функціонування туристичної галузі, то вона $є$ системою економічних процесів, під дією яких попит та пропозиція на туристичний про- дукт приходять у рівновагу. Функціонування туристичного ринку можна представити, як на схемі, зображеній на рис. 1, яка показує, що попит на послуги у сфері туризму обумовлений бажаннями та смаками туристів. На туристичному ринку відбувається рух потоків грошових коштів і туристичного продукту, які рухаються назустріч один одному, але кінцевий результат залежить від внутрішніх та зовнішніх факторів, завдяки яким формуються попит та пропозиція.

На рис. 1 простежуються чинники, що впливають на формування попиту та пропозиції на туристичні товари та послуги. Відзначимо, що попит породжує лише один фактор, однак ним є споживачі туристичних товарів та послуг. Пропозиція з боку підприємств туристичної галузі формується під дією різних ресурсів, а також роботи безпосередньо самих підприємств туристичної галузі. Головною метою функціонування туристичного ринку є отримання максимального прибутку за допомогою залучення все більшої кількості туристів. Всі зусилля підприємств туристичної галузі, туристичних агентів, а також інших працівників прямо чи опосередковано стосуються виробництва туристичного продукту, надання туристичних послуг, мають бути зацікавлені в розкручуванні українських туристичних ресурсів, залученні туристів до видатних місць для отриманні від цього вигоди.

Д. Дей визначає, що маркетинг та інновації-це все, що приносить прибуток компанії, решта є витратами [1]. Маркетинг в туризмі - це процес планування та розроблення відповідної стратегії просування туристичного продукту на ринок, допомога у ціноутворенні, стимулювання збуту, рекламна кампанія.

Термін «комунікація» 3'явився в науковій літературі на початку XX століття. Сьогодні немає єдиної точки зору на термін «комунікація». В англійському тлумачному словнику наводяться такі визначення комунікації: «повідомлення»; «передача інформації або обмін інформацією»; «наука про передачу інформації» [2, с. 732].

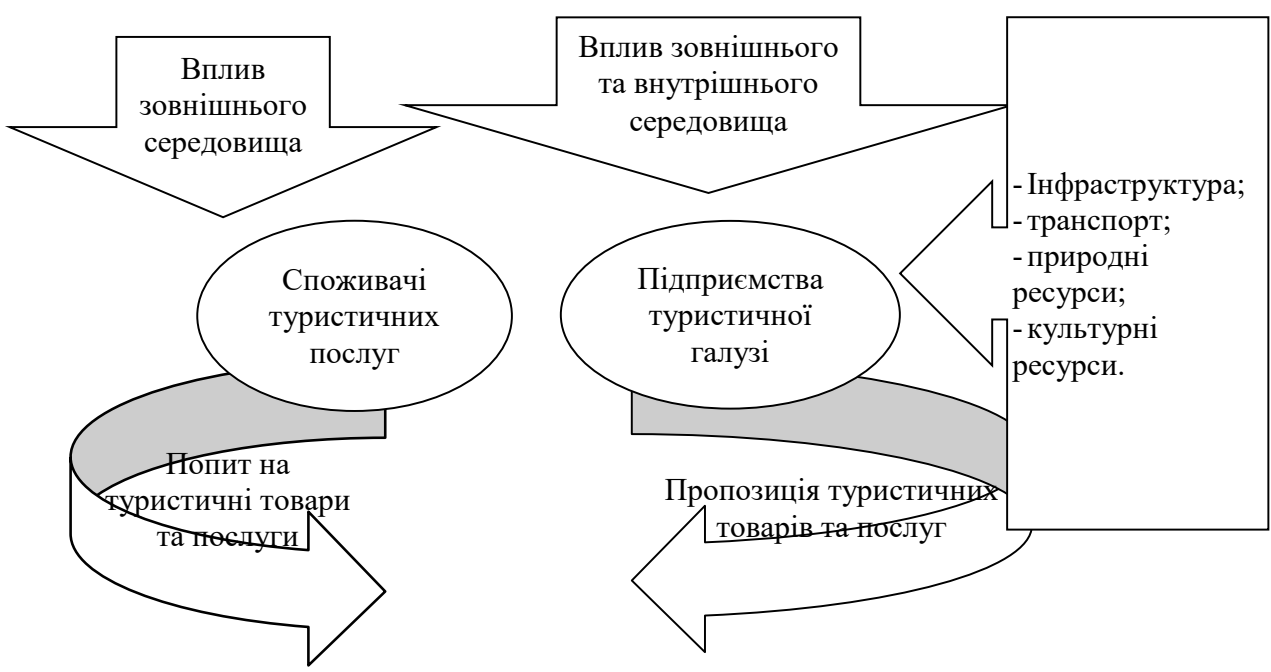

Рис. 1. Функціонування туристичного ринку 
Ж.-Ж. Ламбен під комунікацією розуміє обмін сигналами між передавачем і приймачем із застосуванням системи кодування-декодування для запису та інтерпретації сигналів [3, с. 553].

Маркетингові комунікації є важливою частиною як масових, так і особистих комунікацій, формуючи значну частину інформаційного простору сучасного суспільства та маючи власну специфіку.

Так, група таких авторів, як Ж.-Ж. Ламбен, Р. Чумпітас, I. Шулінг, під маркетинговими комунікаціями розуміє всі види сигналів і повідомлень, орієнтованих фірмою на різні аудиторії, а саме на споживачів, дистриб'юторів, постачальників, акціонерів, органи влади, а також на ії власний персонал. На рис. 2 представлено процес комунікацій з огляду на циркулярну модель Ч. Осгуда та У. Шрамма [4], що включає такі елементи, як відправник, кодування, інформаційне звернення, засіб комунікації, декодування, отримувач, зворотний зв'язок, результат комунікацій, перешкоди в комунікаціях, комунікаційні канали.

3 огляду на особливості використовуваного засобу інформації повідомлення спочатку кодується в прийнятний для передачі вид, а після здійснення факту передачі декодується для надання одержувачу у зручному та зрозумілому вигляді. На всіх етапах процесу комунікації повної передачі інформації існують перешкоди. Для ефективної комунікації поля сприйняття відправника й одержувача мають хоча б частково збігатися.

Нині немає єдиного підходу до визначення поняття «маркетингові комунікації». Аналіз представлених різними авторами варіантів його трактування дає змогу зробити висновок та запропонувати, що найбільш повне й точне визначення маркетингових комунікацій має містити інформацію про характер такої діяльності, iii тривалість, мету, сторін, що беруть участь, використовувані інструменти, наявність зворотного зв'язку. При цьому визначення не має трактуватися надто широко, охоплюючи коло питань, які належать до інших елементів комплексу маркетингу.

За останні три десятиліття роль комунікацій для успішної діяльності туристичного підприємства та ефективного просування товарів і послуг істотно зросла, що стало наслідком серйозних змін, що сталися не тільки зі світом маркетингу, але й зі зміною життєвого укладу людей по всій планеті. Ці зміни лягли в основу появи та розвитку концепції ІМК, що стала природною реакцією на падіння ефективності традиційних інструментів маркетингових комунікацій. Основними факторами цього стали перехід до інформаційного суспільства, збільшення кількості інформації, зниження ефективності реклами, зміна споживчих переваг, глобалізація.

Розвиток інформаційних технологій та збільшення кількості засобів цифрової комунікації стали причинами переходу від постіндустріального суспільства до інформаційного, в якому основними факторами успіху стали знання, дані, телекомунікації як спосіб доставки й поширення цієї інформації. Сьогодні саме інформація та технології є головними виробничими силами, а боротьба за увагу споживача відбувається задовго до здійснення покупки. Важливою характеристикою сучасного ринку є загальний інформаційний простір, у якому маркетингові комунікації набувають вирішального значення, оскільки виступають в ролі одного 3 видів споживаної людьми інформації, але збільшення кількості інформації привело до зниження ефективності реклами та вибірковості людини до неї.

Якщо у 1965 р. звичайний покупець пам'ятав 34\% рекламних роликів, до 1990 р. це цифра зменшилась до $22 \%$, то у 2007 році за підсумками глобального опитування покупців, проведеного “АC Nielsen”, вдалося з'ясувати, що в середньому з усіх коли-небудь побачених рекламних роликів люди змогли назвати тільки

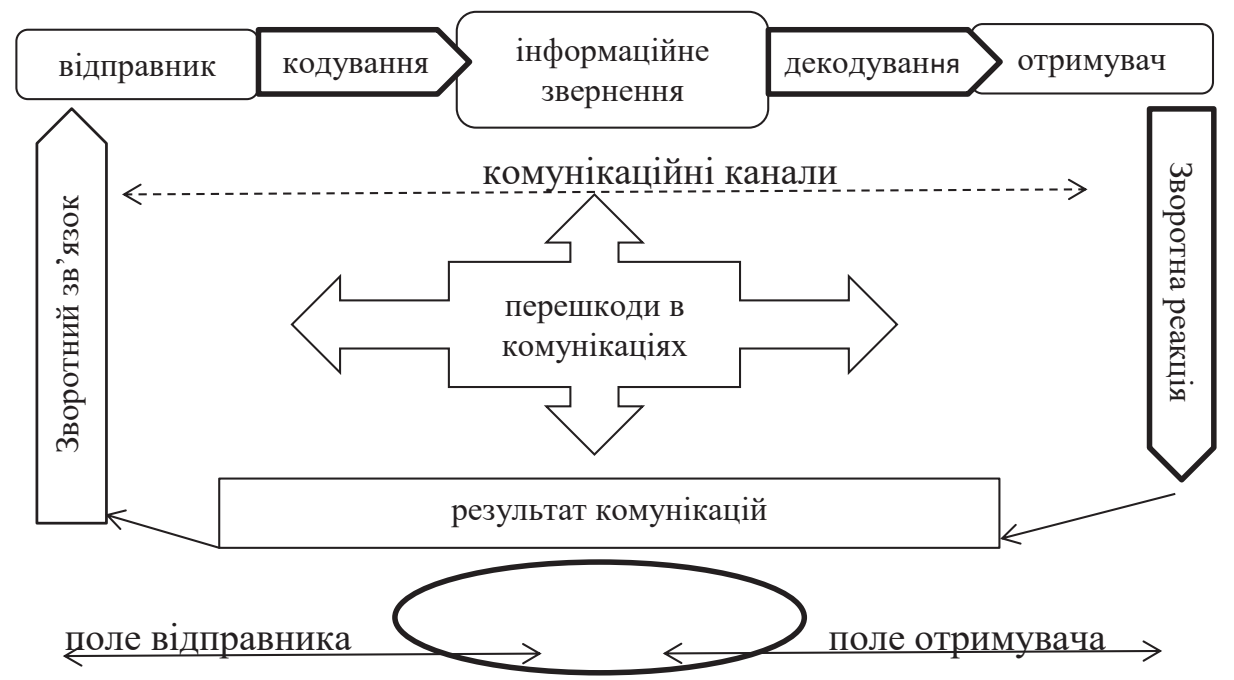

Рис. 2. Процес комунікацій

Джерело: сформовано автором на основі джерела [4] 
2,21\% [5, с. 41]. У зв’язку з цим виникає потреба диверсифікації маркетингових комунікацій для донесення інформації до споживачів за допомогою різних засобів комунікації, а також отримання зворотного зв'язку.

Нові технології стирають географічні та міжкультурні кордони, завдяки чому доступ до різних товарів і послуг (особливо в туристичній галузі), а також до інформації про них істотно спрощується. Люди стають більш мобільними, поступово збільшуються трудова міграція та спеціалізація окремих регіонів земної кулі. У зв'язку з цим підвищується рівень очікувань, який висувається до якості туристичних товарів і послуг, повноти інформації, що надається туристичними підприємствами про свою діяльність і продукцію; 3'являються нові вимоги суспільства, що закликають до відкритої та повної комунікації між компаніями та їх клієнтами.

Представлені фактори поставили питання про створення комплексних систем, у яких різні елементи комунікації будуть використовуватися одночасно, доповнюючи й розвиваючи один одного, а також створюючи синергетичний ефект. Подібні системи отримали назву інтегрованих маркетингових комунікацій. На думку Т. Йешіна, основною причиною інтеграції є бажання комунікатора досягти згуртованості в повідомленнях, які він доставляє [6, с. 68].

Проаналізувавши підходи науковців і маркетологів до визначення інтегрованих маркетингових комунікацій, виділимо такі притаманні їм елементи:

- комунікації мають стратегічний характер;

- в основі інтегрованих маркетингових комунікацій лежить довгострокове планування;

- комунікації повинні сприйматись як безперервний процес, що включає аналіз, вибір, реалізацію та контроль усіх елементів маркетингових комунікацій;

- використовуються різні інструменти й каналів комунікацій для досягнення максимальної ефективності повідомлень;

- вони спрямовуються на поліпшення й підтримку бренду, репутації;

- вони спрямовуються на збільшення прибутку й доданої вартості;

- єдиним є вхід і вихід інформації для досягнення несуперечності та чіткості окремих повідомлень;

- результатом інтеграції є досягнення синергетичного ефекту.

Зазначимо, що частина вчених, наприклад П. Сміт, К. Беррі, А. Пулфорд, Дж. Росситер і Л. Персі, вважають, що вплив інтегрованих маркетингових комунікацій має бути сфокусовано на споживачах, замовниках і клієнтах; сприймають інтегровані маркетингові комунікації тільки як спосіб взаємної інтеграції різних каналів комунікації в рамках просування товарів і послуг. Водночас Д. Шульц, С. Танненбаум, Р. Лаутеборн і П. Валлен пишуть про те, що інтегровані маркетингові комунікації мають контролювати всі аспекти комунікацій як поза організацією, так і всередині неї, крім споживачів. Такими групами є партнери компанії, постачальники, органи державної влади, акціонери, персонал тощо. Це виносить інтегровані маркетингові комунікації на рівень стратегічного менеджменту компанії. Нині дослідники виділяють три основні форми комунікацій, а саме масові комунікації та просування, особисті комунікації, пропаганда, кожна $з$ яких є актуальною для подієвої активності.

Інтернет значно спрощує для покупців процес аналізу даних про туристичний товар або послугу, прискорює та змінює процес покупки. Нині Інтернет є платформою для ділової активності, інструментом, який стрімко розвивається, допомагаючи просувати послуги. Способи надання послуг, іншими словами, правила маркетингу постійно змінюються, компанії все частіше вдаються до використання інформаційних технологій для пошуку способів надання впливу як на наявних клієнтів, так і на потенційних.

Сьогодні існує велика кількість інтернет-спільнот, де діяльність людей зі схожими інтересами відбувається за допомогою інтернет-комунікацій. Виділяють такі інтернет-спільноти, як пабліки в соціальних мережах, блоги, тобто авторські щоденники, форуми, гостьові книги, тобто маленькі чати на сайтах. Кілька 3 цих спільнот можуть бути задіяні для ефективного маркетингу. Наприклад, дослідження “UNWTO” [7] показує ефективність використання таких засобів для просування послуг у сфері гастрономічного туризму, як соціальні мережі “Facebook”, “Twitter”, "Instagram”, "YouTube", онлайн-платформи для реклами за допомогою блогерів. Також великою популярністю користуються сайти-агрегатори, оскільки у них є система пошуку, фільтри, вони забезпечують збирання й сортування необхідної інформації.

Дослідження Мексиканської Інтернет-Асоціації “AMIPICI" [8] доводить, що інтернет-користувачі 3 Мексики вважають, що під час здійснення покупки в соціальних мережах на них здійснюється більший вплив, ніж у реальному житті, адже 59\% заявили, що зробили покупку через наданий на них вплив, 60\% зробили покупку, перейшовши по рекламному посиланню, а більше $60 \%$ опитаних заявляють, що зацікавлені в покупці саме через соціальні мережі. Також соціальні мережі використовуються для аналізу, моніторингу та спілкування з клієнтами в режимі реального часу. Вони забезпечують середовище, яке дає змогу вивчати й аналізувати масивні маркетингові дані, стратегію продажів, рекламну кампанію й прямі відносини з клієнтом. Як досліджувані компанії ми вибрали туристичні агентства, туроператори, готелі та ресторани. Аналіз показав, що використання соціальних мереж приводить до досягнення поставлених цілей [9].

У зв'язку з тим, що більшість компаній зараз рекламує свій продукт саме через соціальні мережі, стає необхідним вжиття маркетингових інтернет-заходів щодо просування продукту або послуг через спілкування $з$ представниками цільової аудиторії в соціальних ресурсах. Туризм є однією з таких сфер діяльності. Рекомендованими інструментами в туризмі є: 
- створення та подальша реклама тематичних продуктів;

- робота 3 просування наявного продукту у соціальні мережі однієї тематики;

- просування продукту через мобільні додатки;

- інтеграція сайту фірми із соціальними мережами;

- створення унікальних посилань;

- ведення та просування корпоративних блогів;

- проведення конференцій та вебінарів онлайн.

Саме завдяки соціальним мережам багато туристичних фірм мають можливість вийти на більший прибуток від реалізації свого продукту, новий рівень ведення бізнесу та сформувати певну репутацію завдяки відгукам клієнтів у соціальних мережах. Послуги можуть бути представлені такими роботами:

- проведення необхідних досліджень і розроблення стратегії;

- створення бренд-платформи та iï якісне наповнення;

- залучення аудиторії та робота 3 нею;

- PR у соціальних мережах;

- контроль результативності просування.

Під час використання соціальних мереж у діяльності туристичної фірми треба враховувати, що існують певні помилки, яких не треба припускатися. Такими помилками можуть бути довгі відповіді на запитання клієнтів, відсутність свого власного стилю (унікальності), опис в одному пості одразу всіх пропозицій фірми, велика кількість зайвих елементів у тексті (стікери), неробочі посилання, відсутність аналізування коментарів потенційних клієнтів.

Необхідно зазначити, що у багатьох підприємств туристичної галузі обмежені фінансові можливості, які не дають на всю потужність використовувати потенціал маркетингових комунікацій, тому перспективним напрямом функціонування $є$ поєднання зусиль підприємств туристичної галузі, громадських організацій та влади, що дасть змогу ефективно використовувати й фінансові, й трудові ресурси в комплексі маркетингових комунікацій, забезпечити розвиток туристичної галузі та задоволення попиту на туристичний продукт і послуги, пропоновані підприємствами туристичної галузі.

Висновки. Отже, резюмуючи все вищесказане, можемо зробити висновок, що туризм набув нині широких масштабів серед усіх країн і став здійснювати сильний вплив на світову економіку. Ефективний розвиток туристичного бізнесу значно збільшує потік іноземних громадян в інші країни, що впливає на зростання податкових відрахувань до бюджету, допомагає розвитку суміжних галузей економіки, підвищує відсоток зайнятості населення, а також дає можливість подорожуючим отримати нові враження й позитивні емоції.

3 огляду на дослідження можна сказати, що підприємства туристичної галузі активно залучають маркетинг у свою діяльність, розробляючи креативні способи просування, різноманітні плани та запускаючи рекламні акції. В умовах сучасного активного розвитку туризму маркетингова діяльність стає однією $з$ найважливіших для утримання стійких позицій на ринку та стимулювання збуту продукту.

Кожне підприємство туристичної галузі, формуючи систему маркетингових комунікацій, має орієнтувати власну діяльність на отримання прибутку та розвиток, використовуючи інструменти маркетингу.

\section{Список літератури:}

1. Дэй Д. Организация, ориентированная на рынок. Как понять, привлечь и удержать ценных клиентов. Москва : Эксмо, 2008. 304 с.

2. Oxford Russian Dictionary. 4th ed. / Oxford, New York : Oxford University Press, 2007. 1322 p.

3. Ламбен Ж.-Ж., Чумпитас Р., Шулинг И. Менеджмент, ориентированный на рынок / пер. с англ. под ред. В.Б. Колчанова. 2-е изд. Санкт-Петербург : Питер, 2014. 720 с.

4. Schramm W. How Communication Works. The Process and Effects of Mass Communication. Urbana : University of Illinois Press, 1954.

5. Линдстром M. Buyology: увлекательное путешествие в мозг современного потребителя / пер. с англ. Е.В. Фалюк. Москва : Манн, Иванов, Фербер ; Эксмо, 2013. 208 с.

6. Yeshin T. Integrated Marketing Communications. The holistic approach. Butterworth-Heinemann, 1999.320 p.

7. Affiliate Members Report, Volume sixteen - Second Global Report on Gastronomy Tourism, UNWTO, Madrid, 2017. $198 \mathrm{p}$.

8. AMIPICI, Mexican Internet Association. "E-Business in Mexico in 2013". Banco Mundial. Doing Business report, 2014.

9. Otoniel J., Rodríguez S. Marketing through Social Networks in Touristic and Gastronomy Industry in Manzanillo, Colima, México. Proceedings of the International Conference on Global Business, Economics, Finance and Social Sciences (20-22 February 2015). Bangkok, Thailand, 2015. P. 268-274

\section{References:}

1. Dej D. (2008) Organizaciya, oriyentovana na ry’nok. Yak zrozumity', zaluchy’ty'j utry’maty’ cinny’x kliyentiv [The Market Driven Organization: Attracting And Keeping Valuable Customers]. Moskva : Eksmo (in Russian).

2. Oxford Russian Dictionary. (2007) 4th edition / Oxford, New York : Oxford University Press. 
3. Lamben Zh. -Zh., Chumpitas R., Shuling I. (2014) Menedzhment, oryentyrovannii na rinok [Market-oriented management]. Sankt-Peterburg : Piter (in Russian).

4. Schramm W. (1954) How Communication Works. The Process and Effects of Mass Communication. Urbana : University of Illinois Press.

5. Lindstrom M. (2013). Buyology: zaxoplyuyucha podorozh v mozok suchasnogo spozhy'vacha [Buyology a fascinating journey into the brain of the modern consumer] Moscow: Mann, Ivanov, Ferber ; Eksmo (in Russian).

6. Yeshin T. (1999) Integrated Marketing Communications. The holistic approach. Butterworth-Heinemann.

7. World Tourism Organization (2017). Affiliate Members Report, Volume sixteen - Second Global Report on Gastronomy Tourism, UNWTO, Madrid.

8. AMIPICI, Mexican Internet Association (2014) “E-Business in Mexico in 2013”. Banco Mundial. Doing Business report.

9. Jesús Otoniel, Sosa Rodríguez (2015) Marketing through Social Networks in Touristic and Gastronomy Industry in Manzanillo, Colima, México Proceedings of the International Conference on Global Business, Economics, Finance and Social Sciences (GB15_Thai Conference) 20-22 February 2015, Bangkok, Thailand.

\section{ФОРМИРОВАНИЕ МАРКЕТИНГОВЫХ КОММУНИКАЦИЙ ТУРИСТИЧЕСКОГО ПРЕДПРИЯТИЯ}

В статье исследованы и обобщены теоретико-методические подходы к формированию маркетинговых мероприятий на предприятии туристической отрасли, а также представлено собственное видение и исследована роль маркетинга в практической деятельности туристических предприятий в современных условиях хозяйствования. Рассмотрены особенности функционирования туристического рынка. Предложено более широкое определение маркетинговых коммуникащий с учетом уже сущзествующих авторских подходов. Доказано, что развитие информационных технологий и увеличение количества средств циирровой коммуникации стали причинами перехода от постиндустриального общества к информационному, в котором основными факторами успеха стали знания, данные, телекоммуникации как способ доставки и распространения этой информации. Таким образом, для предприятий туристической отрасли возникает потребность диверсификации маркетинговых коммуникаций для донесения информации до потребителей с помощцью различных средств коммуникации, а также получения обратной связи, ведь от эффективного использования маркетингового инструментария зависит дальнейшее развитие туристического предприятия в условиях рынка.

Ключевые слова: маркетинг, туризм, маркетинговые коммуникации, интегрированные маркетинговые коммуникации, инструменты маркетинга.

\section{FORMATION OF MARKETING COMMUNICATIONS TOURIST COMPANY}

The article investigates and generalizes theoretical and methodological approaches to the formation of marketing activities in the tourism industry, outlines its own vision and explores the role of marketing in the practical activity of tourism enterprises in modern conditions of management. Currently, the tourism sector is developing very fast and is one of the leading sectors of the economy. Due to the relevance of the topic of planning their vacations, sightseeing tours, etc., in the market of providing tourist services, enterprises of the tourism industry are facing new challenges in the effective sale of goods and services. Travel services include the full range of basic and additional services provided by various organizations in the tourism industry, from travel companies to catering. Features of functioning of tourist market are considered. A broader definition of marketing communications is proposed, taking into account existing authoring approaches. It has been proven that the development of information technology and the increasing number of digital communications have led to the transition from a post-industrial society to an information one, in which knowledge, data, telecommunications are the main success factors for delivering and disseminating this information. The Internet greatly simplifies the process of analyzing information about a tourist product or service for buyers, speeding up and changing the purchase process. Today, the Internet is a platform for business activity, a rapidly evolving tool that helps promote tourism products and services. Thus, for the tourism industry there is a need to diversify marketing communications to convey information to consumers through various means of communication, as well as to receive feedback, further development of the tourism enterprise depends on market conditions, effective use of marketing tools. The instability of the environment, the high level of competition among tourism enterprises in saturated market conditions make them overestimate the management of tourism enterprises and change the approaches to the enterprise management system of the tourism industry.

Key words: marketing, tourism, marketing communications, integrated marketing communications, marketing tools. 